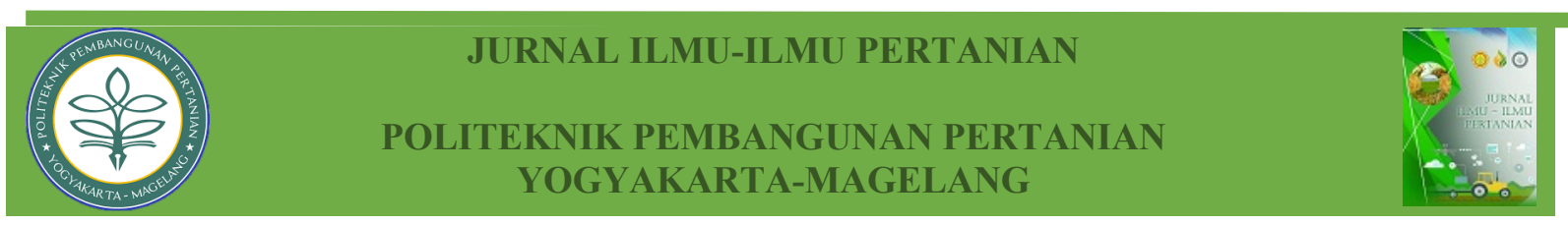

\title{
PENGARUH PUPUK ORGANIK CAIR DAN ASAM HUMAT PADA BUDIDAYA KEDELAI
}

\author{
Budi Wijayanto1, Anang Sucahyo2 \\ ${ }^{1}$ Polbangtan Yogyakarta Magelang, Yogyakarta, 55167 \\ ${ }^{2}$ Dinas Pertanian dan Pangan Kab. Kulon Progo, 55652
}

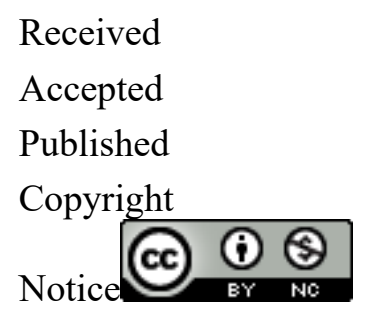

: October $3^{\text {rd }}, 2021$

: Ocober $10^{\text {th }}, 2021$

: November $17^{\text {th }}, 2021$

: Authors retain copyright and grant the journal right of first publication with This work is licensed under a Creative Commons Attribution-Non Commercial 4.0 International License.

ABSTRAK: Penelitian ini mengkaji penggunaan pupuk organik cair (POC) dan asam humat pada budidaya kedelai. Pupuk organik cair yang digunakan dalam penelitian ini menggunakan bahan air leri (air cucian beras), urine kelinci, air kelapa dan rendaman kotoran kambing yang difermentasi. penelitian ini dilaksanakan di lahan Balai Penyuluhan Pertanian (BPP) Galur, Kulon Progo dengan 15 ulangan $x 3$ perlakuan (kontrol; POC dan asam humat) x 2 lokasi (lahan Karang Sewu dan lahan Pandowan) dengan menggunakan varietas Grobogan. Hasil penelitian menunjukkan aplikasi asam humat dan POC akan meningkatkan produktivitas kedelai secara signifikan.

Kata kunci: air leri, urine kelinci, air kelapa, kotoran kambing, asam humat, produktivitas kedelai

ABSTRACT: This study examined the use of liquid organic fertilizer (POC) and humic acid in soybean cultivation. The liquid organic fertilizer used in this study made from leri water (rice washing water), rabbit urine, coconut water and fermented goat manure. The-research was carried out at the Galur Agricultural Extension Center (BPP), Kulon Progo with 15 replications $x 3$ treatments (control; POC and humic acid) $x 2$ locations (Karangsewu land and Pandowan land) using the Grobogan variety. The results showed that the application of humic acid and POC can significantly increase the soybean productivity.

Keywords: rice washing water, rabbit urine, coconut water, goat manure, humic acid, soybean productivity

\section{PENDAHULUAN}

Produksi kedelai dari tahun ke tahun mengalami penurunan signifikan, walaupun terlihat fluktuatif. Selain itu luas areal panen juga mengalami hal yang sama dengan keadaan produksi. Penurunan luas areal tanam dan produksi tanaman kedelai nasional antara lain disebabkan oleh penurunan harga riil kedelai dan adanya persaingan dengan komoditas tanaman lain, yaitu komoditas yang memiliki harga riil lebih tinggi dan segi pemeliharaan lebih tinggi BPS (Anonim, 2017).

Penurunan areal tanam dan produksi juga berpengaruh terhadap penurunan produktivitas kedelai di Indonesia. Rata-rata, produktivitas petani kedelai Indonesia hanya mampu 
menghasilkan 1,2 ton per hektar. Angka tersebut jauh lebih rendah dibandingkan dengan produktivitas negara-negara penghasil kedelai lainnya seperti Brazil dan Argentina, yang mampu menghasilkan di atas 2 juta ton per hektar kedelai. Penurunan produktivitas kedelai tersebut sebagai kenyataan akan ketidakmampuan petani untuk menghasilkan kedelai dengan areal tanam yang ada (Anonim, 2017).

Salah satu upaya untuk meningkatkan produktivitas kedelai adalah pemberian pemupukan dengan pupuk organik cair. Pupuk cair lebih mudah terserap oleh tanaman karena unsur- unsur di dalamnya sudah terurai. Kelebihan dari pupuk cair adalah kandungan haranya bervariasi yaitu mengandung hara makro dan mikro, penyerapan haranya berjalan lebih cepat karena sudah terlarut, (Hadisuwito, 2007).

Hasil penelitian (Tettrinica Meirina, Sri Darmanti, Sri Haryanti, 2015) menunjukkan bahwa pemupukan dengan pupuk organik cair lengkap dapat meningkatkan produktivitas tanaman kedelai, tetapi perbedaan dosis yang diberikan pada tanaman memberikan hasil berbeda tidak nyata. Waktu pemupukan pada pagi dan sore hari menyebabkan produktivitas tanaman kedelai lebih tinggi dibandingkan pada siang hari. Pemupukan pada sore hari berbeda nyata terhadap pemupukan siang hari.

\section{METODE}

Pupuk organik cair yang digunakan dalam penelitian ini menggunakan bahan air leri (air cucian beras), urine kelinci, air kelapa dan kotoran kambing yang direndam dalam POC tersebut selama proses fermentasi. Ke semua bahan difermentasi selama 2 minggu dengan menambahkan EM 4. Hasil penelitian Milawati Lalla (2018) menunjukkan bahwa air cucian beras berpengaruh tidak nyata terhadap pertumbuhan tanaman seledri. Pemberian air cucian beras juga memberikan efek positif pada bobot kering tanaman (Wardiah,et.al.,2014). Air cucian beras mengandung zat pengatur tumbuh. ZPT pada tanaman yang berperan merangsang pembentukan akar dan batang serta pembentukan cabang akar dan batang dengan menghambat dominasi apical dan pembentukan daun muda (Bahar, 2016).

Selain air leri, hasil penelitian Enny Mutryarny, Endriani dan Sri Utami Lestari (2014) menunjukkan bahwa pemberian pupuk organik cair urine kelinci berpengaruh nyata terhadap semua parameter yang diamati, yaitu tinggi tanaman, jumlah daun, lebar daun, bobot segar dan bobot konsumsi tanaman sawi.

Bahan selanjutnya air kelapa merupakan cairan endosperm yang mengandung senyawa organik (Budiono, 2004). Senyawa organik tersebut diantaranya adalah auksin dan sitokinin. Auksin berfungsi dalam menginduksi pemanjangan sel, mempengaruhi dominansi apikal, penghambatan pucuk aksilar dan adventif serta inisiasi perakaran sedangkan sitokinin berfungsi untuk meransang pembelahan sel dalam jaringan dan meransang pertumbuhan tunas (Salisbury dan Ross, 1995). Leovici et al. (2014) menyatakan bahwa pemberian air kelapa muda dengan konsentrasi 25\% mampu meningkatkan pertumbuhan tanaman tebu.

Bahan terakhir yang digunakan adalah kotoran kambing. Hasil penelitian Trisna et al. (2017) pupuk kotoran kambing dapat menambah ketersediaan hara bagi tanaman dan meningkatkan kesuburan tanah. Pupuk Kotoran kambing mengandung nilai rasio $\mathrm{C} / \mathrm{N}$ sebesar 21,12\% (Cahaya dan Nugroho, 2009). Selain itu, kadar hara kotoran kambing mengandung $\mathrm{N}$ sebesar 1,41\%, kandungan $\mathrm{P}$ sebesar 0,54\%, dan kandungan $\mathrm{K}$ sebesar 0,75\% (Hartatik, 2006).

Selain pupuk organik cair penelitian ini juga menguji aplikasi asam humat. Penggunaan asam humat untuk meningkatkan pertumbuhan dan produktivitas tanaman telah menjadi 
perhatian utama para periset dalam beberapa dekade terakhir ini. Asam humat merupakan suatu molekul kompleks yang terdiri atas kumpulan berbagai macam bahan organik yang berasal dari residu hasil dekomposisi tanaman dan hewan. Sebagian besar asam humat diperoleh dari ekstraksi bahan leonardite atau lignit (Tan 2014).

Informasi mengenai potensi asam humat telah banyak dilaporkan, namun yang terkait dengan korelasi asam humat dalam meningkatkan perkembangbiakan bakteri dan fungi di dalam tanah tekstur berpasir masih sangat terbatas. Sinergi kinerja gugus karboksil, fenolik, polisakarida, dan protein dari asam humat, fitohormon dan mikroorganisme tanah dapat membantu meningkatkan pertumbuhan dan produktivitas tanaman.

Beberapa penelitian menyampaikan potensi asam humat dalam membantu meningkatkan kesehatan tanah khususnya meningkatkan penyimpanan karbon pada tanah miskin kadar C-organik (Yeo et al. 2015; Hartz dan Bottoms 2010) dan pertumbuhan mikroorganisme tanah (Tikhonov et al. 2010; Canellas and Olivares 2014; Laksmita Prima Santi, 2016).

Penelitian ini mengkaji aplikasi pupuk organik cair dengan asam humat. Variasi kedua bahan ini masih jarang diaplikasikan dalam budidaya kedelai. Oleh karena itu mengkaji pengaruh penggunaan pupuk organik cair dan asam humat.
Penelitian ini dilaksanakan di lahan

Balai Penyuluhan Pertanian (BPP) Kecamatan Galur, Kulon Progo yang terletak di Desa Karangsewu dan Desa Pandowan, Galur, Kulon Progo. Jenis tanah di lokasi grumosol berwarna merah kelabu tua, bukan induk dari batu kapur dan mejal. Penelitian dilaksanakan April Agustus 2018 dan varietas yang digunakan adalah varietas Grobogan.

Penelitian ini mengkaji variasi pemupukan dengan POC dan penggunaan asam humat dengan 15 ulangan $x \quad 3$ perlakuan (kontrol; POC dan asam humat). Aplikasi POC dan asam humat dengan pengocoran sebanyak 3 kali yaitu sebelum penanaman, 20 HST dan 35 HST (hari setelah tanam). Parameter yang diamati adalah produktivitas. Produktivitas dihitung dengan menimbang dengan timbangan dengan mengubin seluas $2,5 \mathrm{~m}$ x 2,5 m selanjutnya dikonversi menjadi berat biji kering untuk satuan ton/ha. Analisis data menggunakan Uji Anova diikuti dengan Uji Duncan. Kedua lokasi (Karangsewu dan Pandowan) dijadikan sebagai variabel kontrol. Oleh karena itu dilakukan uji Anova dan uji multivariate. Dalam analisis ini menggunakan software SPSS versi 20.00 .

\section{HASIL PENELITIAN}

Penelitian dilakukan dari dua (2) lokasi di lahan BPP Kecamatan Galur yaitu di Desa Pandowan dan Karangsewu. Hasil penelitian dapat dilihat pada Tabel 1.

Tabel 1. Produktivitas kedelai (ton/ha) di berbagai lokasi dan perlakuan

\begin{tabular}{lrlrlll}
\hline & \multicolumn{2}{c}{ Pandowan } & \multicolumn{2}{c}{ Karangsewu } & \multicolumn{2}{c}{ Rerata } \\
\hline kontrol & 0,6858 & a & 0,9558 & b & 0,8208 & x \\
\hline asam humat & 1,9772 & d & 1,7620 & d & 1,8696 & y \\
\hline POC & 1,9626 & d & 1,5285 & c & 1,7456 & y \\
\hline Rerata & 1,5419 & p & 1,4154 & p & + & \\
\hline
\end{tabular}

Keterangan

Huruf yang sama menunjukkan tidak ada perbedaan yang signifikan untuk tingkat signifikansi 5\%.

Tanda + menunjukkan lokasi dan perlakuan secara bersama-sama mempengaruhi produktivitas. 
Dari Tabel 1 menunjukkan bahwa aplikasi asam humat akan meningkatkan produktivitas. Dari 0,6858 ton/ha menjadi 1,9772ton/ha (asam humat) dan 1,9626 ton/ha (POC) di Pandowan dan 0,9558 ton/ha menjadi 1,762 ton/ha (asam humat) dan 1,5285 (POC) di Karangsewu.

Dengan kata lain asam humat di Pandowan meningkatkan produktivitas sebesar 188,31\%, sedangkan POC meningkatkan produktivitas sebesar 186,18\%. Di lokasi Karangsewu asam humat mampu meningkatkan produktivitas sebesar 84,35\% dan POC sebesar 59,92\%.

Secara umum asam humat mampu meningkatkan produktivitas menjadi 1,8696 ton/ha sedangkan POC 1,7454 ton/ha dari yang semula 0,8208 ton/ha. Dengan kata lain asam humat meningkatkan produktivitas sebesar $127,78 \%$ dan POC sebesar $112,67 \%$.

Dari uji $\mathrm{F}$ menunjukkan aplikasi asam humat dan POC akan meningkatkan produktivitas tanaman kedelai.

Hal ini ditunjukkan pada Tabel 1 aplikasi asam humat dan POC menunjukkan perbedaan yang signifikan dengan kontrol untuk tingkat signifikansi 5\%. Sedangkan untuk aplikasi asam humat dan POC tidak menunjukkan perbedaan yang signifikan

Pada lahan Karangsewu produktivitas kedelai berbeda untuk aplikasi asam humat dan POC, sedangkan untuk lahan Pandowan tidak menunjukkan perbedaan. Artinya lokasi lahan Pandowan menunjukkan bahwa perlakuan aplikasi asam humat dan POC menunjukkan perbedaan yang signifikan dengan kontrol dengan tingkat signifikansi 5\%. Sedangkan untuk perlakuan antara asam humat dan POC tidak menunjukkan perbedaan yang signifikan. Hal ini berbeda dengan lokasi di Karangsewu, dimana aplikasi asam humat menunjukkan produktivitas yang tertinggi disusul dengan asam humat dan terakhir kontrol.

Data sebelum aplikasi menunjukkan bahwa produktivitas di Pandowan lebih rendah dibandingkan di
Karangsewu. Sedangkan untuk aplikasi asam humat menunjukkan bahwa di kedua lokasi tidak menunjukkan perbedaan yang signifikan. Sedangkan aplikasi menunjukkan bahwa produktivitas di Pandowan lebih tinggi dibanding di Karangsewu. Secara umum di kedua lokasi tidak menunjukkan perbedaan yang signifikan.

Dari uji nultivariate menunjukkan ketika lokasi dikombinasikan dengan perlakuan (aplikasi asam humat dan POC) menunjukkan perbedaan yang signifikan (ditunjukkan dari tanda + ). Hal iini ditunjukkan dari nilai $\mathrm{F}$ hitung sebesar 10,0349 dengan nilai signifikansi 0,0001 . Dari Tabel 1 menunjukkan bahwa perlakuan mempengaruhi produktivitas, lokasi tidak mempengaruhi produktivitas dan kombinasi perlakuan dan lokasi menunjukkan perbedaan yang signifikan.

\section{KESIMPULAN}

Dari analisis di atas menunjukkan bahwa aplikasi asam humat dan POC akan meningkatkan produktivitas kedelai secara signifikan. Hasil untuk setiap lokasi bisa menunjukkan hasil yang berbeda.

\section{PUSTAKA ACUAN}

Alexander, M, 1977, Introduction to Soil Microbiologi, 2nd edition, john Wiley and Sons, New York.

Anonim, 2017, Manfaat dan Kelebihan Pupuk Organik Cair didownload dari http://www.kebunpedia.com pada tanggal 24 Oktober 2017

Bahar, A. E. 2016. Pengaruh Pemberian Limbah Air Cucian Beras Terhadap Pertumbuhan kangkung darat (Ipomoea reptans L.). Artikel Ilmiah Program Studi Agroteknologi Fakultas Pertanian Universitas Pasir Pengaraian, Riau.

Budiono, D.P. 2004. Multiplikasi in vitro tunas bawang merah (Allium ascalonicum L) pada berbagai taraf 
konsentrasi air kelapa. Jurnal Agronomi, Volume 8 (2) : 75-80.

Cahaya, A.T. dan Nugroho D.A. 2008. Pembuatan Kompos dengan Menggunakan Limbah Padat Organik (Sampah Sayuran dan Ampas Tebu). Artikel Ilmiah, Teknik Kimia Universitas Diponegoro. Semarang:

Canellas, L.P. dan F.L. Olivares. 2014. Physiological responses to humic substances as plant growth promoter. Chem. Biol. Technol.Agric. 1(3): 111.

Fauzi. 2010. Uji Beberapa Jenis Microorganisme Selulolitik Terhadap Pertumbuhan dan Produksi Kedelai (Glycine max L.) di Lahan Gambut. Skripsi. Fakultas Pertanian. Universitas Riau. Pekanbaru.

Hadisuwito, S. 2007. Membuat Pupuk Kompos Cair. PT Agromedia Pustaka. Jakarta.

Hartatik, W. Dan Widowati, L.R. 2006. Pupuk Kandang, Pupuk Organik dan Pupuk Hayati. Artikel Ilmiah, Bogor: Balai Besar Penelitian dan Pengembangan Sumber Daya Lahan Pertanian.

Hartz, T.K dan T.G. Bottoms. 2010. Humic substances generally ineffective in improving vegetable crop nutrient uptake or productivity. Hort. Sci 45(6): 906- 910.

Hidayat, Omar O, 1985, Morfologi Tanaman Kedelai, Balai Tanaman Pangan Sukamandi, Bandung

Ichriani, Gusti I, dkk. 2008. Perkembangan Bintil Akar Dan Hasil Tanaman Kedelai (Glycine max L. Merril) Varietas Wilis Ditanah Gambut Akibat Pemberian Pupuk Organik Padat. Jurnal Ilmiah. UNPAR. 22 (2): 69-75

Leovici H, D. Kastono, E. T. S. Putra. 2014. Pengaruh macam dan konsentrasi bahan organik sumber zat pengatur tumbuh alami terhadap pertumbuhan awal tebu (Saccharum officinarum L.). Jurnal Vegetalika. Vol 3 (1): 22-34.

Milawati Lalla, 2018. Potensi Air Cucian Beras sebagai Pupuk Organik pada Tanaman Seledri (Apium Graveolens L.), Jurnal Agropolitan, Volume 5 Nomor 1 Bulan Juli 2018

Mulyani, Kertasaputra dan Sastroatmodjo, 1991, Mikrobiologi Tanah, Rineka Cipta, Jakarta

Mutryarny, E; Endriani dan Lestari,SU, 2014, Pemanfaatan Urine Kelinci Untuk Meningkatkan Pertumbuhan dan Produksi Tanaman Sawi (Brassica Juncea L) Varietas Tosakan, Jurnal Ilmiah Pertanian Vol.11 No.2 Februari 2014

Nini, R. 2005. Pemanfaatan Biofertilizer Pada Pertanian Organik. Jurnal Pertanian. Balai Penelitian Tanaman Kacang-kacangan dan Umbi-umbian (Balitkabi). Malang.

Norman, AG, 1978, Soybean, Physiology, Agronomy and Utilization, Univ Michigan, New York

Pasaribu, D, 1980, Effect Nitrogen Fertilizatioan and Inoculation on Performance and Yield of Soybean, Univ. Philippines, Los Banos

Risnawati. 2010. Pengaruh Pemberian Pupuk Urea Dan Beberapa Formula Pupuk Hayati Rhizobium Terhadap Pertumbuhan Dan Hasil Kedelai (Glycine max (1.) Merril) Di Tanah Masam Ultisol. Skripsi. Universitas Islam Negeri Maulana Malik Ibrahim. Malang

Salisbury, F.B dan C.W Ross. 1995. Fisiologi Tumbuhan (Jilid 2). ITB. Bandung.

Santi, L.P. 2016, Pengaruh Asam Humat terhadap Pertumbuhan Bibit Kakao (Theobroma cacao) dan Populasi Mikroorganisme di dalam Tanah Humic Dystrudept, Jurnal Tanah dan Iklim Vol. 40 No. 2 Hal. 87-94

Sari, D. F, 2011, Analisis Daya Saing dan Strategi Pengembangan Agribisnis Kedelai Lokal di Indonesia, Working 
Paper, Badan Ketahanan Pangan Departemen Pertanian 2009.

Simanjuntak, N.B.L. 2007. Respon Tanaman kedelai (Glycine max (L) Merril) Terhadap Perbedaan Dosis Berbagai Jenis Kapur di Tanah Gambut. Skripsi. Fakultas Pertanian. Universitas Riau. Pekanbaru.

Sofia, Da. 2007. Respon Tanaman Kedelai (Glycine max (L) Merril) pada Tanah Masam. Working Paper. Universitas Sumatera Utara. Medan.

Somaatmadja, S, M. Ismunadji, Sumarno, M. Syam, S.O. Manurung dan Yuswadi, 1985, Kedelai, Pusat Penelitian dan Pengembangan Tanaman Pangan, Bogor

Subba rao, N.S. 1977, Microorganism and Plant Growth., Oxford and IBH Publishing Co., New Delhi

Suharjo, Usman KJ. 2001. Efektifitas Nodulasi Rhizobium japonicum Pada Kedelai Yang Tumbuh di Tanah Sisa Inokulasi dan Tanah dengan Inokulasi Tambahan.Jurnal Ilmu Pertanian. Universitas Bengkulu. 3 (1): 31-35

Surawinoto, 1977, Respon Kedelai Clark 63 Normal dan Clark Uji terhadap Pemupukan N, , Tesis, IPB, Bogor

Tan, K.H. 2014. Humic Matter in Soil and the Environment : Principles and Controversies, 2nd Edition. Apple Academic Press, Inc. Oakville, Canada. 495 p.

Tettrinica Meirina, Sri Darmanti, Sri Haryanti, 2015, Produktivitas Kedelai (Glycine max (L.) Merril var. Lokon) yang Diperlakukan dengan Pupuk Organik Cair Lengkap Pada Dosis dan Waktu Pemupukan yang Berbeda, working paper, Lab. Biologi Struktur Dan Fungsi Tumuhan, Jurusan Biologi MIPA UNDIP

Tikhonov, V.V., A.V. Yakushev, Y.A. Zavgorodnyaya, B.A. Byzov, dan V.V Demin. 2010. Effect of humic acid on the growth of bacteria. Soil Biology. 43(3): 305-313.

Trisna Afriadi Muhammad, Badruz Zaman, Purwono, 2017, Pengaruh Penambahan Pupuk Kotoran Kambing terhadap Hasil Pengomposan Daun Kering di TPST UNDIP, Jurnal Teknik Lingkungan, Vol. 6, No. 3

Wardiah, Linda dan Rahmatan, 2014. Potensi Limbah Air Cucian Beras SebagaiPupuk Organik Cair pada Pertumbuhan Pakchoy (Brassica rapa L.). Jurnal Biologi Edukasi Edisi 12 Vol. 6 No.1 Juni 2014, Hal 34-38.

Weber, D.F, B.E. Caldwell, S. Slogger and H.G Vest, 1971, Some USDA Studies Soybean Rhizobium Symbiosis, Plant Soil Spec, vol 239304

Wersa. W., 1994. Pengaruh Takaran dan Cara Penempatan Pupuk NPK Terhadap Pertumbuhan, Komponen Hasil dan Hasil Kedelai (Glycine $\max ($ L) Merril). Skripsi. Universitas Borobudur. Jakarta. 